\title{
THE METHOD OF COORDINATED TRAINING FOR JOINT ACTIONS OF FORCES OF SECURITY AND DEFENSE SECTOR OF UKRAINE OF DIFFERENT AFFILIATIONS IN THE CONTEXT OF AN INTERNATIONAL COOPERATION (ON THE EXAMPLE OF BORDER SECURITY GUARANTEEING ENTITIES)
}

\section{Dmytro Kupriyenko}

\section{INTRODUCTION}

Despite the complexity of the military-political and socio-economic situation, the border policy of Ukraine is aimed at maximum consolidation of the potential of the entities of the security and defense sector of the state (law enforcement agencies and military units) in order to guaranteeing national security ${ }^{1}$. In particular, built in 2010, Integrated Border Management (hereinafter - IBM) system moved in 2019 to a new stage of development by increasing the number of entities of this system, and also optimizing their entities in the vector of ensuring an adequate border security level that, in particular, is one of the criteria of realization of Eurointegration course of Ukraine ${ }^{2,3}$.

So, in particular, in the National Security Strategy of Ukraine ${ }^{4}$ in the provision on the creation of an effective security and defense sector, it is

${ }^{1}$ Shynkaruk O. M., Lysyi M. I., Kupriyenko D. A. (2019) Suchasnyi stan prykordonnoho bezpekovoho seredovyshcha Ukrainy [The modern state of the border security environment of Ukraine]. Scientific Works of Kharkiv National Air Force University, Vol. 3(61), pp. 135-145. https://doi.org/10.30748/zhups.2019.61.17. (in Ukrainian)

${ }^{2}$ Rozporiadzhennia Kabinetu Ministriv Ukrainy vid 24 lypnia 2019 r. № 687-r (2019) Pro skhvalennia Stratehii intehrovanoho upravlinnia kordonamy na period do 2025 roku [On the approval of the Integrated Border Management Strategy for the period up to 2025]. Retrieved from: https://zakon.rada.gov.ua/laws/show/687-2019-\%D1\%80 (accessed 12 Jan. 2020). (in Ukrainian)

${ }^{3}$ Mizhnarodnyi dokument vid 27.06.2014 (2014) Uhoda pro asotsiatsiiu mizh Ukrainoiu, z odnoho boku, ta Yevropeiskym Soiuzom, Yevropeiskym spivtovarystvom z atomnoi enerhii i yikhnimy derzhavamy-chlenamy, $\mathrm{z}$ druhoho boku [Association Agreement between Ukraine, of the one part, and the European Union, the European Atomic Energy Community and their Member States, of the other part]. Retrieved from: https://zakon.rada.gov.ua/go/984_011 (accessed 12 Jan. 2020). (in Ukrainian)

${ }^{4}$ Ukaz Prezydenta Ukrainy vid 26.05.2015 № 287/2015 (2015) Pro rishennia Rady natsionalnoi bezpeky i oborony Ukrainy vid 6 travnia 2015 roku „Pro Stratehiiu natsionalnoi bezpeky Ukrainy" [On the decision of the National Security and Defense Council of Ukraine of May 6, 2015 "On the National Security Strategy of Ukraine"]. Retrieved from: https://zakon.rada.gov.ua/go/287/2015 (accessed 12 Jan. 2020). (in Ukrainian) 
stated that the formation and development of the security and defense sector, which should provide an adequate and flexible response to threats, rationally using opportunities and resources, is a priority of national security policy. At the same time, it is necessary to ensure: the introduction of an integrated system of education, combat and special training of personnel of the security and defense sector with the involvement of teachers, instructors from NATO Member States, the European Union (EU), the formation of a new security culture.

Item, nowadays, intensive processes of political, socio-economic, defense and security synchronization and harmonization are obviously taking place in the European region. Therefore, the issues of building a "space of freedom, security and justice/due process of law", as well as a deep and comprehensive free trade area, remain relevant on the agenda. The center of gravity of this problem is gradually shifting from the internal to the external dimension of the EU, which opens up more opportunities for cooperation with countries that have common borders (Eastern Partnership countries) $)^{5,6}$.

Within the framework of this policy, one of the main vectors of the activities of the European Union is the construction / modernization / improvement of the border security guaranteeing (hereinafter - BSG) system, which would guarantee open, but at the same time controlled and safe external borders between the states. However, these requirements for the BSG system are quite contradictory. On the one hand, it should effectively counteract real and potential threats at a certain level (local, national, regional and international (global)), and on the other hand, it should fully comply with the standards/requirements/norms of legitimate crossborder activities and respect for fundamental human rights.

To this end, the European Commission has developed and in 2002 implemented a border policy, which was officially called "Integrated Border Management"7. At the same time, it should be emphasized that there are other concepts indicating the need for a more complete interaction of all

\footnotetext{
${ }^{5}$ Bodruk O. S. (2001) Struktury voiennoi bezpeky: natsionalnyi ta mizhnarodnyi aspekty : monohrafiia [Military security structures: national and international aspects: monograph]. Kyiv : $N I P M B, 300$ p. (in Ukrainian)

${ }^{6}$ Brezhnieva T., Yizhak O., Shevtsov A. (2003) Yevroatlantychna intehratsiia Ukrainy: viiskovo-politychni aspekty : monohrafiia [Ukraine's Euro-Atlantic integration: militarypolitical aspects: monograph]. Dnipropetrovsk : Porohy, 160 p. ISBN: 966-525-424-3. (in Ukrainian)

7 Communication to the Council and the European Parliament. Towards integrated management of the external borders of the member states of the European Union. Brussels, 7 May 2002, $\operatorname{COM(2002)~} 0233$ final, 28 p. Retrieved from: https://eur-lex.europa.eu/legalcontent/EN/TXT/?uri=celex:52002DC0233 (accessed 12 Jan. 2020). (in Ukrainian)
} 
actors whose activities are in one way or another related to border and crossborder activities, for example, it can be integrated, coordinated, coherent, joint border management, but it does not significantly affect the practice of border policy ${ }^{8,9,10}$.

It is important to note that the development and adoption of national concepts (strategies) BSG is one of the mandatory criteria for readiness for European integration (in the systems of Copenhagen and Madrid criteria $^{11,12}$. For example, the BSG mechanism was implemented to varying degrees in the public administration system of the Member States of the European Union ${ }^{13}$, the Eastern Partnership countries (Armenia, Azerbaijan, Belarus, Georgia, Moldova, Ukraine), countries of Africa and Central Asia. In particular, for Ukraine, the first stage of the action Plan on visa liberalization ${ }^{14}$ was provided:

approval of the National Strategy for IBM and an Action Plan for its effective implementation, which defines a time frame and specific goals for the development of legislation, organization, infrastructure, facilities, as well

\footnotetext{
${ }^{8}$ EuropeAid (2010) Cooperation Office Guidelines for Integrated Border Management in European Commission External Cooperation. Brussels, 152 p. Retrieved from: https://europa.eu/capacity4dev/file/21153/download?token=31OSGDjf (accessed 12 Jan. 2020). (in Ukrainian)

${ }^{9}$ McLinden G., Fanta E., Widdowson D. and Doyle Th. (2010) Border Management Modernization: A Practical Guide for Reformers : conference edition. Washington, D.C.: The World Bank. Retrieved from: https://pdfs.semanticscholar.org/6043/4817c84ea9a4d74187 4fc98301b8bc2bb843.pdf (in Ukrainian)

${ }^{10}$ Doyle T. (2010) Collaborative border management. World Customs Journal, vol. 4, no. 1, pp. 15-21. ISSN: 1834-6707 (Print) 1834-6715 (Online). Retrieved from: https://worldcustomsjournal.org/Archives/Volume\%204\%2C\%20Number\%201\%20(Mar\%202 010)/00\%20Complete\%20Issue\%20WCJ_Volume_4_Number_1.pdf (accessed 12 Jan. 2020). (in Ukrainian)

${ }^{11}$ Hrytsiak I. A., Dzvinchuk D. I. (ed.) (2013) Yevropeiska intehratsiia : navchalnyi posibnyk dlia studentiv vyshchykh navchalnykh zakladiv ta slukhachiv mahisterskoi pidhotovky za napriamom «Derzhavne upravlinnia» [European integration: a textbook]. IvanoFrankivsk: Misto NV, 464 p. (in Ukrainian)

${ }^{12}$ Melnykov O. H. (2011) Derzhavne upravlinnia u sferi prykordonnoi bezpeky v umovakh yevropeiskoi intehratsii Ukrainy [Public administration in the sphere of border security in terms of Ukraine European integration] (PhD Thesis), National Academy of Public Administration the President of Ukraine, p. 234. (in Ukrainian)

${ }^{13}$ European Commission (EC) (2007) Guidelines for Integrated Border Management in the Western Balkans (2004, update: 2007). Retrieved from: https://www.legislationline.org/ documents/id/16809 (accessed 12 Jan. 2020). (in Ukrainian)

${ }^{14}$ Mizhnarodnyi dokument vid 22.11.2010 (2010) Bezvizovyi dialoh mizh Ukrainoiu ta YeS. Plan dii z liberalizatsii vizovoho rezhymu [Visa-free dialogue between Ukraine and the EU. Visa Liberalization Action Plan]. Retrieved from: https://zakon.rada.gov.ua/laws/show/ 984_001 (accessed 12 Jan. 2020). (in Ukrainian)
} 
as sufficient financial and human resources in the field of border management;

implementation of training programmes and adoption of anti-corruption codes of ethics that directly affect border officials, customs officials and other officials involved in border management;

and at the second stage (criteria for effective implementation):

ensuring adequate infrastructure, technical equipment, IT-technologies, financial and human resources in accordance with the adopted Strategy of IBM; effective implementation of training programs and anti-corruption measures;

improvement of interagency cooperation (including exchange of information between the border service and law enforcement agencies), international cooperation, especially the implementation of Working agreements with Frontex.

The basis for the implementation of the BSG is a coordinated and harmonized activity between all relevant authorities and services responsible for border security and trade facilitation (these are all agencies responsible for combating cross-border crime, border control, customs procedures, traffic safety, terrorist, migration and other types of security $)^{15,16,17}$.

All this indicates an increase in the scale of border activities, its network nature and a significant increase in the capacity of the BSG system, built on the IBM principles.

It should be pointed out that the expansion of border management inevitably leads to the emergence of new factors that can cause (especially in the early stages of the implementation of the BSG system) significant difficulties in management and, accordingly, lead to the leveling of the effectiveness of the entire BSG mechanism. The reasons for such difficulties are the following:

${ }^{15}$ Varga Ja., Kupriyenko D., Mironau D., Gaspar Z. (2015) Methodological approach to developing national differentiated training in integrated border management in Eastern Partnership countries. Magyar rendészet: a Nemzeti Közszolgálati Egyetem Rendészettudományi Karának szakmai, tudományos folyóirata, vol. XV/3, pp. 111-120. ISSN 1586-2895. Retrieved from: https://matarka.hu/nyomtat.php (accessed 12 Jan. 2020). (in English)

${ }^{16}$ Rozporiadzhennia Kabinetu Ministriv Ukrainy vid 15.11.2017 № 1023-r (2017) Pro skhvalennia Stratehii rozvytku orhaniv systemy Ministerstva vnutrishnikh sprav na period do 2020 roku [On approval of the Strategy of development of the bodies of the Ministry of Internal Affairs system for the period up to 2020]: Retrieved from: https://zakon.rada.gov.ua/laws/show/ 1023-2017-\%D1\%80 (accessed 12 Jan. 2020). (in Ukrainian)

${ }^{17}$ European Commission (EC) (2007) Guidelines for Integrated Border Management in the Western Balkans (2004, update: 2007). Retrieved from: https://www.legislationline.org/ documents/id/16809 (accessed 12 Jan. 2020). (in Ukrainian) 
increasing the number of entities that must provide border security according to a single plan;

intensification of planning and implementation of joint activities by border security guaranteeing entities (hereinafter - BSGE);

strengthening cooperation with international organizations (e.g. INTERPOL, Europol, Frontex Agency, International Organization for Migration (IOM), International Centre for Migration Policy Development (ICMPD), World border organization (BORDERPOL), World Customs Organization (WCO), etc.) as well as other stakeholders (carriers/operators, public, etc.).

In turn, these features lead to new higher requirements for personnel, because in the framework of the issue under consideration, the human factor is the most significant in terms of its influence on the possibility of using the BSG potential. In this regard, BSGE are obliged to pay considerable attention to the selection, training and motivation of personnel.

\section{Literature review}

A significant amount of research in various fields of social and humanitarian knowledge is devoted to the study of personnel management issues. The fundamental foundations of the problem are laid in the works of well-known scientists in the field of European integration, motivation, social management, management of the organization and the like. In modern research on the selection, training and motivation of personnel of organizations, the main attention is focused on the importance of using a unified approach, which contributes to the interaction of structures in various spheres of public life, including in the field of IBM as an innovative BSG mechanism $^{18,19,20,21}$.

At the same time, the results of the analysis of these studies, as well as the experience of training in BSG allow us to assert that:

${ }^{18}$ EuropeAid Cooperation Office (2010) Guidelines for Integrated Border Management in European Commission External Cooperation. Brussels, 152 p. Retrieved from: https://europa.eu/capacity4dev/file/21153/download?token=31OSGDjf (accessed 12 Jan. 2020). (in English)

${ }^{19}$ Frontex Agency (2012) Common Core Curriculum. EU Border Guard Basic Training. Warsaw, 104 p. Retrieved from: http://www.statewatch.org/news/2012/mar/frontex-ccctraining.pdf (accessed 12 Jan. 2020). (in English)

${ }^{20}$ Organization for Security and Cooperation in Europe (OSCE), United Nations Economic Commission for Europe (UNECE) (2012) Handbook of Best Practices at Border Crossings - A Trade and Transport Facilitation Perspective. Luxembourg: Imprimerie Centrale S.A., 268 p. ISBN: 978-3-9502218-8-6. Retrieved from: https://www.osce.org/secretariat/ 88238?download=true (accessed 12 Jan. 2020). (in English)

${ }^{21}$ Vajta I., Varga Ya. (2007) A Schengeni Határellenőrzési Kódex. E-Learning tananyag. Társszerzö. IRM Oktatási Föigazgatóság. (in Hungarian) 
(a) the issues of recruitment and motivation of personnel have been studied in depth and widely disclosed, and the selection and adaptation of rational approaches among them in the interests of border security does not cause difficulties;

b) issues related to scientific and methodological support and teaching methods for the formation and teaching of a training course on BSG have certain features, namely:

there are training and methodological materials on BSG developed by different departments, educational institutions and international organizations (textbooks, manuals, lectures, distance learning programs), however, they are usually either used on the principle of "all for all", or, in response to departmental interests, are highly specialized, internally oriented, and this can lead to a violation of the principle of "consistency" of knowledge in the general environment of training of personnel for BSGE;

the most complex and responsible issues are the formation of the educational content of disciplines(s), the distribution of educational time by forms and types of classes, as well as on individual issues, the justification of the necessary time for the study of the discipline;

noticeable distortions of information (through the gap in theory and practice and hierarchy of decision-making system), as well as significant temporal inertia from the moment of actual changes taking place in the field of BSG to the use in the field of education;

there are no scientific materials devoted to the study of the problem of formation of the training course and instilling competence to BSG.

Thus, these signs illustrate high probability of inharmoniousness of the system of training (education) of personnel for the BSG sphere, which, in turn, creates high risks of insufficient provision of national and international border interests. Taking this into account, the issue of developing an appropriate system of training becomes relevant, taking into account the features of the conceptual design of the training system in the BSG field. At the same time, the results that are expected to be achieved should ensure the formation of the competence of all personnel in the BSG field according to a single plan and to the required extent.

\section{Materials and methods}

According to the results of the analysis of works, in particular ${ }^{22}$, it is possible to develop a system of training using the capabilities of competence

${ }^{22}$ Blauberg I. V., Yudin E. G. (1973) Stanovlenie i suschnost sistemnogo podhoda [The system approach's formation and essence]. Moscow: NAUKA, 270 p. Retrieved from: http://tlf.msk.ru/school/Blauberg.pdf (accessed 12 Jan. 2020). (in USSR) 
and system approaches. In the aspect of our research the following characteristic features of competence approach in education (professional training) are of the greatest interest:

1) strengthening of practical orientation of training, its focus on future professional activity (that is, the shift of emphasis from the accumulation of normative certain knowledge and skills to the formation and development of future professionals the ability to act effectively in practice);

2) significant improvement of adaptation of young employees to job requirements with a predetermined (in the process of training) list of competencies and modeling of job situations;

3) the possibility to justify the system of program-target quality management of professional training.

In turn, the system approach is the main, generic scientific method of analysis of any studied pedagogical phenomenon and therefore it can be interpreted as a methodological direction, the task of which is to develop principles, methods and means of studying objects, including those relating to the system of training in the BSG field.

To develop a training system based on competence-based and systematic approaches, it is necessary to form its future desired image, which can be set in the form of certain requirements.

The first (main) - the set of competencies of the personnel of all BSGE of the should provide an effective solution to all problems of BSG.

Second - the competence of certain categories of BSGE personnel should be formed in the part that concerns them.

Third, the personnel of all BSGE categories should have systematic understanding of the activities of other entities.

Fourth - the content of the training system should be kept up to date (that is, changes in the BSG field should be delivered to the education sector without distortion and with minimal delay).

In our opinion, it is possible to develop a model of the training system that meets reasonable requirements, acting on the following methodology:

I. Organization of work on the formation of the training system:

1. The national coordination center of BSG on the basis of analysis of normative-legal base should identify the full range of BSGE of and initiate the establishment of a working group composed of experts-representatives and consultants - the leading experts in the BSG field of the relevant international and foreign organizations, to implement a scheme shown in the figure (numbers indicate the stages of the methodology).

II. Formation of training content and structure of its provision:

2. Identify the tasks that need to be solved to achieve the goals of BSG at each level (local, regional, national, interstate, international). 
3. On the basis of tasks to formulate all basic competences which the BSGE personnel for their successful performance (ensuring) has to have. It is also important to determine which of them are private (specific) for each BSG level, and which are common and the basis for other competencies (for example, communication skills, knowledge of foreign languages).

4. Define within entities the nomenclature of categories (positions) of the personnel which duties include accomplishment of BSG tasks.

5. Define personal competencies for each category of personnel and the level/degree of involvement of personnel in the performance of specific tasks).

6. To form a differentiated national training program for the training of BSG personnel (hereinafter - DNTP BSG) as a set of united by a single idea of especial training programs (hereinafter - TP) for different categories of personnel, as well as all employees of the BSGE. For effective application, timely monitoring of the relevance of competencies and continuous improvement, the mandatory elements of the program should be:

6.1. Informative part:

- recommended frequency of DNTP BSG monitoring;

- general methodology for the formation of DNTP BSG;

- customers of personnel - BSGE (contact information);

- educational / training institutions/centres (ETIC) (contact information), where the recruitment of personnel for each of the BSGE is carried out; their subordination to a higher authority (contact information);

- mechanisms to influence the adoption of especial BSG curricula for teaching (the Ministry of Education, the BSGE etc., their contact information).

6.2. Content relating to the composition and support of up-to-date state of TP of BSG:

- separate training programs to BSG for different categories of personnel, as well as all employees of the BSGE in the system of training, retraining, advanced training), indicating the technology of training (recommended forms and types of classes, effective methods, necessary educational and material base, etc);

- the results of the audit of training programs that already exist in the ETIC and provide for the formation of competencies in the BSG field, indicating the qualities that they form and those that do not form; the procedure for monitoring and making changes;

- the procedure for the final certification of specialists after the completion of the training program.

6.3. Requirements for teachers in the BSG field (scientific and pedagogical personnel, coaches, instructors, animators), recommendations for their training. Database of necessary data about them. 
6.4. The order to bring information to ETIC, which is preparing personnel for the BSGE, the web address of the resource DNTP BSG (website/portal/information system or relevant tab on the website), the procedure of maintenance and access to information.

6.5. The procedure for maintaining feedback:

- the procedure for the participation of personnel customers in the BSG field in the planning of joint exercises and certification of specialists;

- procedure for selection of candidates for work/service in the BSG field;

- the procedure and results of monitoring the activities of the personnel of the BSGE, which has been trained in BSG TP, with the allocation and categorizing of shortcomings in training (similar to the risk analysis: the scale of the shortage, the probability of occurrence, possible damage). The procedure for their elimination due to changes in the TP of BSG;

- the procedure for maintaining feedback with: ETIC, teachers in the BSG field, BSGE and their experts, with graduates of ETIC.

III. Implementation of training system:

7. To prepare (to retrain, to train) teaching personnel, and also to create necessary educational and material base of ETIC.

8. To provide the teaching personnel with the necessary educational and methodological information on the basis of the web-resource of the DNTP BSG in time.

9. To introduce the TP of BSG in the educational process of the ETIC.

IV. Maintaining the training system:

10. To maintain up-to-date and continuous improvement of the training system to organize sustainable feedback in accordance with paragraph 6.5.

As can be seen from these stages, the organization, development, use and support of the training system in the BSG field is large-scale and objectively requires the involvement of various specialists, both educational and practical levels. In this regard, we have proposed an organizational model of the training system in the BSG field, which is presented in Fig. 1. 


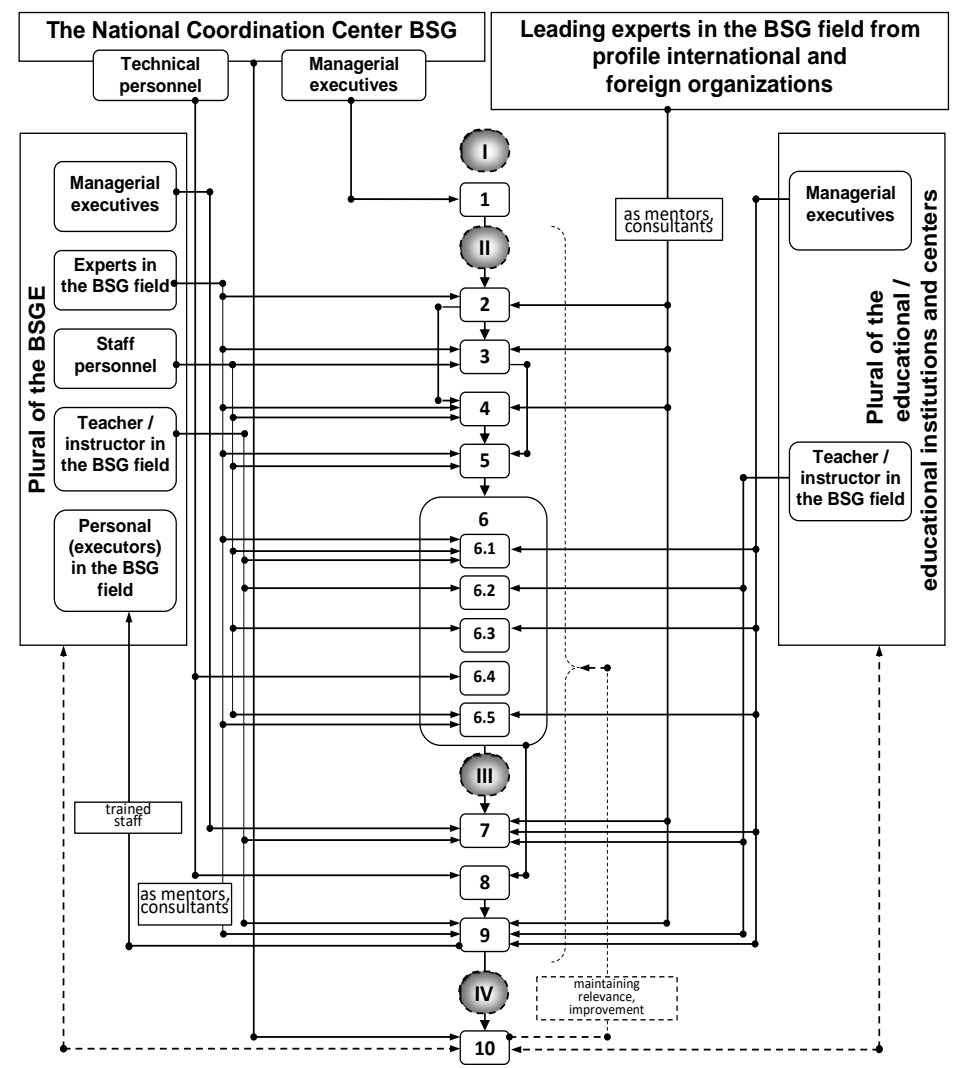

Fig. 1. Structural diagram of the organizational model of the system of coordinated training for joint actions of forces of security and defense sector of Ukraine of different affiliations in the context of an international cooperation (on the example of border security guaranteeing entities) ${ }^{23}$

For the practical implementation of these requirements, the model is proposed, the gist of which are reflected in the table 1.

${ }^{23}$ Varga Ya., Kupriyenko D., Mironov D. (2015) Kontseptualnoe proektirovanie sistemy podgotovki kadrov v sfere integrirovannogo upravleniya granitsami [Conceptual design of a training system in the field of integrated border management]. Zb. nauk. pr. SBGAU, Seriia : viiskovi ta tekhnichni nauky : naukove vydannia. Khmelnytskyi : NADPSU, no. 2 (64), pp. 6-23. (in English) 
Models of formation of generalized matrix of competencies of BSG personnel*

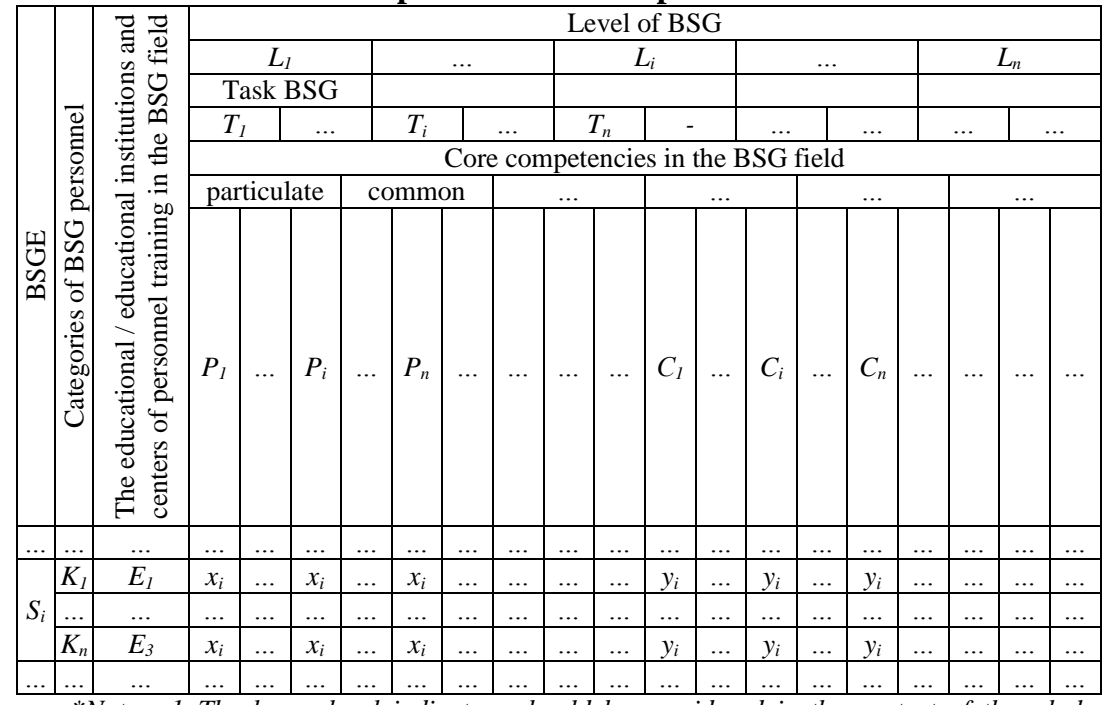

*Notes: 1. The lower level indicators should be considered in the context of the whole hierarchy of indicators, eg: correctly $-S_{1} / K_{3}$ (third category of first BSGE personnel) or $L_{3} / T_{2} / P_{4}$ (fourth competence of second task on the third BSG level); wrong $-C_{2}$ (second common competence).

2. $x_{i}=\left\{v_{1}, \ldots, v i, \ldots, v n\right\}$.

3. $y_{i}=\left\{l_{l}, \ldots, l_{i}, \ldots, l_{n}\right\}$, where $l$ (level) - is the conditional normalized levels of competence, starting from zero and beyond (e.g., English language skills

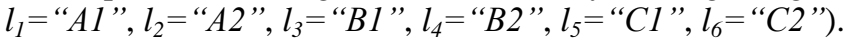

4. The main requirement for the DNTP BSG: "The set of competences of the personnel of all BSGE, that formulated in the DNTP BSG, should ensure that all BSG tasks are solved".

Creating a working design of especial TP for different categories of BSGE personnel (on the example of training of specialists of the State Border Guard Service of Ukraine on documents checking), is published in the article ${ }^{24}$.

24 Kupriyenko D. A., Sychevskyi Yu. O. (2015) Roboche proektuvannia okremoi navchalnoi prohramy zi skladu natsionalnoi dyferentsiiovanoi navchalnoi prohramy pidhotovky kadriv u sferi intehrovanoho upravlinnia kordonamy (na prykladi pidhotovky fakhivtsiv Derzhavnoi prykordonnoi sluzhby Ukrainy $\mathrm{z}$ perevirky dokumentiv) [Working design of a especial training program from the composition of the national differentiated training program for personnel in the integrated border management field (on the example of training of specialists of the State Border Service of Ukraine on document verification)]. Zb. nauk. pr. $S B G A U$, Seriia : viiskovi ta tekhnichni nauky : naukove vydannia. Khmelnytskyi : NADPSU, no. 4 (66), pp. 103-123. (in Ukrainian) 


\section{Results (proposals)}

Particular proposals for the development of the BSG system by preparing the forces of the BSGE for joint actions.

As for the professional training of forces of BSGE for joint action at the national level, first of all, the presence of the following prerequisites should be noted.

\section{Recommended national actions:}

1) in order to increase the responsibility and legal regulation to include in the Plan for the implementation of the IBM Strategy for the period up to 2025 activities related to the training of personnel of different categories in the field of BSG;

2) to implement a systematic approach to the training of personnel of the BSGE develop NDTP BSG;

3) to systematize: specific tasks that are solved in the field of BSG; necessary for the solution of competence; categories of personnel in the field of BSG; identification of educational / training institutions and centers in which training, retraining and advanced training is carried out;

4) to include in the Appendix to the diploma of education (or certificate of training) the competencies possessed by the graduate, including in the field of BSG (for example, on the model of the European practice Transcript of Records, conform Bologna);

5) to the BSGE coordinator to enter the site / portal/information system for NDTP of BSG, to define the corresponding order of support and access;

6) to conduct joint (interdepartmental) training of personnel of different categories and departments in the field of BSG and to introduce trained personnel into the system of departmental / interdepartmental multiplication;

7) to improve the mechanism of interaction of the personnel customers with educational / training institutions and centers;

8) in educational/training institutions and centers to determine the structural and logical links between disciplines that ensure the formation of competencies in the BSG field;

9) for especial lectures, it is advisable to invite qualified representatives of the BSGE (mainly - heads of different levels of management, prominent figures, leading experts, personnel who perform daily duties in the field of BSG, representatives of interacting bodies, scientific and pedagogical personnel from other educational / training institutions and centers);

10)in addition to the current system of training of scientific and pedagogical personnel, to explore the possibility and introduce periodic internships (up to 5 days) on the basis of other BSGE. 


\section{Recommended external support:}

1) to participate in the justification of partial training programs for the training of employees of specific categories;

2) provide organizational assistance in training of multipliers (selection and invitation of relevant experts from international organizations, EU and Eastern partnership countries);

3) to provide technical and financial support in the preparation of projects and activities for the development of a website / portal / information system for the NPTP of the BSG.

On preparation of forces of BSGE for joint actions at the interstate and international levels it is offered.

In the sphere of educational activities:

1) for the purpose of legal regulation of cooperation to conclude bilateral agreements or protocols between educational / educational institutions of BSGE of Ukraine with the relevant institutions of the EU and Eastern partnership States;

2) in order to obtain organizational, scientific, methodological and practical experience:

in the case of planning joint exercises by educational institutions of the EU or Eastern partnership countries, invite representatives of the entities of the educational (in particular, scientific and pedagogical personnel, adjuncts, doctoral students, master's students and cadets) and operational spheres;

to expand opportunities of foreign internships of scientific and pedagogical personnel, adjuncts, doctoral students, students and cadets of educational / training institutions of the BSGE through projects funded by the EU and the USA;

to study the content of the curricula and literature on the BSG (including the course and literature on the English language based on the BSG) developed in the EU and Eastern partnership States for bachelor, master and doctoral students. If necessary, to transfer them to the interested party (or exchange);

take an active part in international scientific conferences in the EU and Eastern partnership countries;

create and maintain up-to-date general catalogue of scientific publications available in educational institutions-signatories of the Memorandum of understanding and cooperation between educational institutions of a number of EU member States and Eastern partnership countries (list of publications, periodicity, procedure for submitting publications);

take an active part in joint research in the field of education and BSG, as well as the publication of joint articles; 
to take an active part in the training activities of the personnel training system of the EU and Eastern Partnership countries entities;

3 ) it is proposed to include in the Strategy provisions to intensify the involvement of international and European organizations (including IOM, OSCE, ICMPD, Frontex) in order to organize and conduct on the basis of the National Academy of the State Border Guard Service of Ukraine named after Bohdan Khmelnytskyi training courses (retraining, advanced training) of various categories of personnel in the interests of border security at the national and regional levels;

4) in order to improve the skills of the management of the BSGE to organize training for them in the relevant educational institutions/centers of the EU member states, as well as in the OSCE Border Management Staff College (R. Tajikistan);

5) after each significant event to issue for the beneficiary a document of a recommendatory nature signed by the Party that organized the event, the introduction of best practices. To organize a second meeting of the Parties after a specified period to discuss the results of the implementation and the circumstances preventing it;

6) for the purpose of rapprochement to take part in sports and cultural events, including professional holidays, held in the EU and the Eastern partnership.

\section{SUMMARY}

Thus, the method of coordinated training for joint actions of forces of security and defense sector of Ukraine of different affiliations in the context of an international cooperation, which allows to carry out conceptual, working and organizational design of system of training of specific categories of the personnel of forces of security and defense sector according to the unified plan and in necessary volume was developed. The method is based on the models that are formed on the basis of the application of competence and system approaches to the training of personnel of security and defense sector, namely: models of differentiated training program on security and defense; organizational model of the system of training for joint actions of forces of security and defense sector; models of formation of generalized matrix of competencies of personnel of forces of security and defense sector.

The solution of the problem of coordinated preparation of forces for joint actions will allow to increase the efficiency of functioning and development of security and defense sector both at the national, and at the international level.

The formed image of the system of personnel training, which is presented in the form of the following requirements: a) a set of competencies 
of personnel of all the security guaranteeing entities needs to provide an effective solution to all security guaranteeing tasks; b) the competence of the especial personnel categories of the security guaranteeing entities need to build on those aspects that concern them; c) personnel of all categories of the security guaranteeing entities needs to have system idea about the activities of other actors; d) the content of the training system need to keep up to date (i.e. changes in the security guaranteeing field, must enroll in education without distortion and with a delay).

\section{REFERENCES}

1. Shynkaruk O. M., Lysyi M. I., Kupriyenko D. A. (2019) Suchasnyi stan prykordonnoho bezpekovoho seredovyshcha Ukrainy [The modern state of the border security environment of Ukraine]. Scientific Works of Kharkiv National Air Force University, Vol. 3(61), pp. 135-145. https:// doi.org/10.30748/zhups.2019.61.17 (in Ukrainian)

2. Rozporiadzhennia Kabinetu Ministriv Ukrainy vid 24 lypnia 2019 r. № 687-r (2019) Pro skhvalennia Stratehii intehrovanoho upravlinnia kordonamy na period do 2025 roku [On the approval of the Integrated Border Management Strategy for the period up to 2025]. Retrieved from: https://zakon.rada.gov.ua/laws/show/687-2019-\%D1\%80 (accessed 12 Jan. 2020). (in Ukrainian)

3. Mizhnarodnyi dokument vid 27.06.2014 (2014) Uhoda pro asotsiatsiiu mizh Ukrainoiu, z odnoho boku, ta Yevropeiskym Soiuzom, Yevropeiskym spivtovarystvom $z$ atomnoi enerhii $i$ yikhnimy derzhavamy-chlenamy, $\mathrm{z}$ druhoho boku [Association Agreement between Ukraine, of the one part, and the European Union, the European Atomic Energy Community and their Member States, of the other part]. Retrieved from: https://zakon.rada.gov.ua/go/984_011 (accessed 12 Jan. 2020). (in Ukrainian)

4. Ukaz Prezydenta Ukrainy vid 26.05.2015 № 287/2015 (2015) Pro rishennia Rady natsionalnoi bezpeky i oborony Ukrainy vid 6 travnia 2015 roku „Pro Stratehiiu natsionalnoi bezpeky Ukrainy” [On the decision of the National Security and Defense Council of Ukraine of May 6, 2015 «On the National Security Strategy of Ukraine»]. Retrieved from: https://zakon.rada.gov.ua/go/287/2015 (accessed 12 Jan. 2020). (in Ukrainian)

5. Bodruk O.S. (2001) Struktury voiennoi bezpeky: natsionalnyi ta mizhnarodnyi aspekty : monohrafiia [Military security structures: national and international aspects: monograph]. Kyiv : NIPMB, 300 p. (in Ukrainian)

6. Brezhnieva T., Yizhak O., Shevtsov A. (2003) Yevroatlantychna intehratsiia Ukrainy: viiskovo-politychni aspekty : monohrafiia [Ukraine's 
Euro-Atlantic integration: military-political aspects: monograph]. Dnipropetrovsk : Porohy, 160 p. ISBN: 966-525-424-3 (in Ukrainian)

7. Communication to the Council and the European Parliament. Towards integrated management of the external borders of the member states of the European Union. Brussels, 7 May 2002, COM(2002) 0233 final, $28 \mathrm{p}$. Retrieved from: https://eur-lex.europa.eu/legalcontent/EN/TXT/?uri=celex:52002DC0233 (accessed 12 Jan. 2020). (in English)

8. EuropeAid (2010) Cooperation Office Guidelines for Integrated Border Management in European Commission External Cooperation. Brussels, 152 p. Retrieved from: https://europa.eu/capacity4dev/file/21153/ download?token=31OSGDjf (accessed 12 Jan. 2020). (in English)

9. McLinden G., Fanta E., Widdowson D. and Doyle Th. (2010) Border Management Modernization: A Practical Guide for Reformers : conference edition. Washington, D.C.: The World Bank. Retrieved from: https://pdfs.semanticscholar.org/6043/4817c84ea9a4d741874fc98301b8bc2b b843.pdf (in English)

10. Doyle T. (2010) Collaborative border management. World Customs Journal, vol. 4, no. 1, pp. 15-21. ISSN: 1834-6707 (Print) 1834-6715 (Online). Retrieved from: https://worldcustomsjournal.org/Archives/Volume $\% 204 \% 2$ C\%20Number\%201\%20(Mar\%202010)/00\%20Complete\%20Issue \%20WCJ_Volume_4_Number_1.pdf (accessed 12 Jan. 2020). (in English)

11. Hrytsiak I. A., Dzvinchuk D. I. (ed.) (2013) Yevropeiska intehratsiia : navchalnyi posibnyk dlia studentiv vyshchykh navchalnykh zakladiv ta slukhachiv mahisterskoi pidhotovky za napriamom "Derzhavne upravlinnia" [European integration: a textbook]. Ivano-Frankivsk: Misto NV, 464 p. (in Ukrainian)

12. Melnykov O. H. (2011) Derzhavne upravlinnia u sferi prykordonnoi bezpeky $\mathrm{v}$ umovakh yevropeiskoi intehratsii Ukrainy [Public administration in the sphere of border security in terms of Ukraine European integration] (PhD Thesis), National Academy of Public Administration. (in Ukrainian)

13. European Commission (EC) (2007) Guidelines for Integrated Border Management in the Western Balkans (2004, update: 2007). Retrieved from: https://www.legislationline.org/documents/id/16809 (accessed 12 Jan. 2020). (in English)

14. Mizhnarodnyi dokument vid 22.11.2010 (2010) Bezvizovyi dialoh mizh Ukrainoiu ta YeS. Plan dii z liberalizatsii vizovoho rezhymu [Visa-free dialogue between Ukraine and the EU. Visa Liberalization Action Plan]. Retrieved from: https://zakon.rada.gov.ua/laws/show/984_001 (accessed 12 Jan. 2020). (in Ukrainian)

15. Varga Ja., Kupriyenko D., Mironau D., Gaspar Z. (2015) Methodological approach to developing national differentiated training in 
integrated border management in Eastern Partnership countries. Magyar rendészet: a Nemzeti Közszolgálati Egyetem Rendészettudományi Karának szakmai, tudományos folyóirata, vol. XV/3, pp. 111-120. ISSN 1586-2895. Retrieved from: https://matarka.hu/nyomtat.php (accessed 12 Jan. 2020). (in English)

16. Rozporiadzhennia Kabinetu Ministriv Ukrainy vid 15.11.2017 № 1023-r (2017) Pro skhvalennia Stratehii rozvytku orhaniv systemy Ministerstva vnutrishnikh sprav na period do 2020 roku [On approval of the Strategy of development of the bodies of the Ministry of Internal Affairs system for the period up to 2020]: Retrieved from: https://zakon.rada.gov.ua/laws/show/1023-2017-\%D1\%80 (accessed 12 Jan. 2020). (in Ukrainian)

17. European Commission (EC) (2007) Guidelines for Integrated Border Management in the Western Balkans (2004, update: 2007). Retrieved from: https://www.legislationline.org/documents/id/16809 (accessed 12 Jan. 2020). (in English)

18. EuropeAid Cooperation Office (2010) Guidelines for Integrated Border Management in European Commission External Cooperation. Brussels, 152 p. Retrieved from: https://europa.eu/capacity4dev/file/ 21153/download?token=31OSGDjf (accessed 12 Jan. 2020). (in English)

19. Frontex Agency (2012) Common Core Curriculum. EU Border Guard Basic Training. Warsaw, 104 p. Retrieved from: http://www.statewatch.org/news/2012/mar/frontex-ccc-training.pdf (accessed 12 Jan. 2020). (in English)

20. Organization for Security and Cooperation in Europe (OSCE), United Nations Economic Commission for Europe (UNECE) (2012) Handbook of Best Practices at Border Crossings - A Trade and Transport Facilitation Perspective. Luxembourg: Imprimerie Centrale S.A., 268 p. ISBN: 978-39502218-8-6. Retrieved from: https://www.osce.org/secretariat/88238? download=true (accessed 12 Jan. 2020). (in English)

21. Vajta I., Varga Ya. (2007) A Schengeni Határellenőrzési Kódex. ELearning tananyag. Társszerzö. IRM Oktatási Föigazgatóság. (in Hungarian)

22. Blauberg I. V., Yudin E. G. (1973) Stanovlenie i suschnost sistemnogo podhoda [The system approach's formation and essence]. Moscow : NAUKA, 270 p. Retrieved from: http://tlf.msk.ru/school/ Blauberg.pdf (accessed 12 Jan. 2020). (in USSR)

23. Varga Ya., Kupriyenko D., Mironov D. (2015) Kontseptualnoe proektirovanie sistemy podgotovki kadrov $\mathrm{V}$ sfere integrirovannogo upravleniya granitsami [Conceptual design of a training system in the field of integrated border management]. Zb. nauk. pr. SBGAU, Seriia : viiskovi ta 
tekhnichni nauky : naukove vydannia. Khmelnytskyi : NADPSU, no. 2 (64), pp. 6-23. (in Ukrainian)

24. Kupriyenko D. A., Sychevskyi Yu. O. (2015) Roboche proektuvannia okremoi navchalnoi prohramy zi skladu natsionalnoi dyferentsiiovanoi navchalnoi prohramy pidhotovky kadriv u sferi intehrovanoho upravlinnia kordonamy (na prykladi pidhotovky fakhivtsiv Derzhavnoi prykordonnoi sluzhby Ukrainy z perevirky dokumentiv) [Working design of a especial training program from the composition of the national differentiated training program for personnel in the integrated border management field (on the example of training of specialists of the State Border Service of Ukraine on document verification)]. Zb. nauk. pr. SBGAU, Seriia : viiskovi ta tekhnichni nauky : naukove vydannia. Khmelnytskyi : NADPSU, no. 4 (66), pp. 103-123. (in Ukrainian)

Information about the author:

Dmytro Kupriyenko,

Deputy Dean for Academic Affairs

of the Faculty of training Managerial executives, The National Academy of the State Border Guard Service of Ukraine named after Bohdan Khmelnytskyi

46 Shevhenka str., Khmelnytskyi, 29007, Ukraine

ORCID ID: orcid.org/0000-0002-4086-1310 